\title{
BIBLIOTEKA-UNIWERSYTET. ZAKŁAD NARODOWY IM. OSSOLIŃSKICH WE WSPOMNIENIACH STANISŁAWA WASYLEWSKIEGO
}

Słowa kluczowe: Ossolineum, Stanisław Wasylewski, Lwów, Stanisław Łempicki, bibliofilstwo

Keywords: Ossolineum, Stanisław Wasylewski, Lviv, Stanisław Łempicki, bibliophily

1.

Nie sposób jest przecenić kulturowe znaczenie Zakładu Narodowego im. Ossolińskich w polskich zaborowych realiach XIX i początków XX wieku. Jego rola została zaprojektowana już około roku 1793, kiedy „kolekcjonerstwo książkowe Ossolińskiego nabrało określonego celu, jakim miało być stworzenie poważnego księgozbioru dla celów społecznych, narodowych"1. Wówczas to Ossoliński, w dużej mierze dzięki Samuelowi Lindemu, powiększał swoje wiedeńskie zbiory, nabywając cenne druki w dworach i w pałacach, a przede wszystkim pozyskując je z księgozbiorów należących do klasztorów likwidowanych w monarchii habsburskiej przy końcu XVIII wieku. W maju 1817 r. „,patriotyczna myśl Ossolińskiego"2 zwieńczona została powołaniem fundacji Biblioteki Narodowej we Lwowie ${ }^{3}$, którą ostatecznie ulokowano w - zakupionym na cele zakładu - budynku poklasztornym ss. karmelitanek.

Utworzona przez Ossolińskiego biblioteka była instytucją „skrojoną” na miarę swojej epoki. Stanowiła odpowiedź na najważniejsze wyzwanie czasu zaborów, jakim - w sytuacji braku struktur państwowych, powołanych w normalnych warunkach do utrzymywania bytu narodowego - stało się zachowanie dziedzictwa narodowej kultury. Z tego właśnie względu Ossolineum - jak napisze w swoich

\footnotetext{
${ }^{1}$ Jan Trzynadlowski, Zakład Narodowy imienia Ossolińskich 1817-1967, zarys dziejów (Wrocław: Zakład Narodowy im. Ossolińskich, 1967), 24.

${ }^{2}$ Ibidem, 24.

${ }^{3}$ Vide Eugeniusz Adamczak, „Wstęp”, in Portrety ossolińskie. Antologia wspomnień, ed. Eugeniusz Adamczak (Wrocław: Zakład Narodowy im. Ossolińskich, 1992), 5.
} 
wspomnieniach Stanisław Łempicki - „było nieporównane z żadną inną biblioteką [...], weszło w zwyczaj, że o Zakładzie Narodowym Ossolińskich mówiło się we Lwowie z pewnym przejęciem, akcentem, szacunkiem, że się go wymieniało bez namysłu przed wszystkimi innymi instytucjami kulturalnymi miasta i kraju"4. Tak ukształtowany kult Ossolineum utrzymywał się przez cały XIX wiek aż do odzyskania niepodległości i wzmacniany był szczególną pozycją Zakładu w zaborze austriackim, w którym dotkliwie dawała o sobie znać polityka germanizacyjna. Łempicki - kontynuując swoje rozważania o fenomenie Zakładu - pisał, że „przyczyna kultu Ossolineum tkwi [...] w równoczesności i organicznym związku rozwoju Ossolineum z dźwiganiem się Lwowa spod ciężaru wieloletniej germanizacji i bezwzględnego władania niemieckiego ducha w 1-szej połowie XIX wieku i później”. Misja, jaka została powierzona bibliotece narodowej, przez cały wiek zaborów zyskiwała na aktualności ze względu na historię narodu żyjącego w ramach różnych organizmów państwowych. We Lwowie przełomu XIX i XX wieku wspierała ją także postawa „ludzi świadomych wychowawczo-patriotycznej roli humanistyki dla cementowania wspólnoty narodowej rozdartej między trzech zaborców”.

2.

Ranga założonej przez Ossolińskiego książnicy - jako instytucji ocalającej polski dorobek kulturowy - zobowiązywała do traktowania jej jako miejsca szczególnego, w którym wymagany był określony sposób bycia. Anegdotyczny wydźwięk może mieć opowieść Mieczysława Opałka o tym, jak jeden ze stałych bywalców czytelni naukowej Ossolineum uciszał rozmawiających w niej młodych ludzi, mówiąc: „- Cicho, nie rozmawiaj! Kształć umysł i serce!”’ . Niemniej jednak ta właśnie, przypomniana przez niego, dość groteskowa, scena bardzo dużo mówi na temat przeżyć, jakie towarzyszyły bywalcom tego miejsca. Przekonuje również, że indywidualne „doświadczenie” biblioteki o tak określonej misji jest istotne, gdyż pozwala zweryfikować jej etos w perspektywie subiektywnych emocji, które stały się udziałem ludzi współtworzących jej historię. Do opisania tak zakreślonego obszaru afirmacji biblioteki Ossolińskich na początku XX wieku skłania również świadomość, że we Lwowie tego czasu rodził się ruch bibliofilski.

${ }^{4}$ Stanisław Łempicki, Wspomnienia ossolińskie (Wrocław: Zakład Narodowy im. Ossolińskich, 1948), 9.

${ }^{5}$ Ibidem, 9-10.

${ }^{6}$ Marceli Kosman, „Stanisław Wasylewski jako znawca i popularyzator historii”, in Z życia i twórczości Stanisława Wasylewskiego. Materiały z sesji naukowej odbytej w Opolu w dniu 12 grudnia 1989 roku (Opole: Wydawnictwo Instytutu Śląskiego w Opolu, 1991), 12.

${ }^{7}$ Mieczysław Opałek, O Lwowie i mojej młodości. Kartki z pamiętnika 1881-1901, posłowiem opatrzył Jan Trzynadlowski (Wrocław: Zakład Narodowy im. Ossolińskich, 1987), 171. 
Kiedy w 1928 r. zorganizowano w tym mieście III Zjazd Bibliofilów Polskich, to zespolono go z obchodami jubileuszu istnienia Zakładu Narodowego im. Ossolińskich ${ }^{8}$, podkreślając tym samym inicjującą rolę Biblioteki Ossolińskich w powstawaniu środowiska kolekcjonerów i wielbicieli książek ${ }^{9}$. Niektórzy spośród lwowskich bibliofilów, zrzeszonych oficjalnie od 1925 r. w ramach Towarzystwa Miłośników Książki ${ }^{10}$, byli wcześniej stypendystami Ossolineum. Wśród nich znajdował się wspomniany już Łempicki oraz Stanisław Wasylewski. Obaj należeli do tegoż Towarzystwa ${ }^{11}$, obaj też opublikowali wspomnienia ze swoich ossolińskich czasów, które są nieocenionymi dokumentami ich bibliotekarskiej pracy. Pozostawione przez nich świadectwo „bibliotecznego życia” nie tylko pozwala więc rozpoznać mechanizm tworzenia się legendy Ossolineum, lecz także dostarcza materiałów do refleksji na temat szerszych kontekstów zainteresowania książką w kulturze polskiej przełomu XIX i XX wieku.

Najciekawsze w tej pespektywie wydają się wspomnienia Pod kopuła lwowskiego Ossolineum, które wyszły spod pióra Wasylewskiego - pisarza, dziennikarza, eseisty, a w latach 1905-1910 wolontariusza, stypendysty, następnie zaś asystenta w Zakładzie ${ }^{12}$. Jego „ossolińska historia” rozpoczęła się od momentu zatrudnienia przy dokumentowaniu i opracowywaniu zbiorów. Pierwsze zadania Wasylewskiego związane były z katalogowaniem woluminów. Jak wspomina, w ciasnym pomieszczeniu ,wicekustosz [Bronisław Czarnik - D.K.] dyrygował pracą 4-6 stypendystów cisnących się przy kilku stolikach i jednym większym stole” (PklO, 80-82), do obowiązków których należało „każdą nowość z zakupu czy z daru sprawdzić w katalogu abecadłowym, a stwierdziwszy jej brak napisać na czerpanym papierze dokładną kartkę do katalogu głównego z określeniem formatu, ilości stronic, tomów, ilustracji, wreszcie miejsca druku” (PklO, 80-82).

Wypisanie pierwszej karty bibliotecznej było symbolicznym aktem rozpoczęcia „ossolińskiej biografii”. Później dopełniała ją praca w biurze obsługi pracowni naukowej w sali katalogowej, gdzie adept pracy bibliotecznej „od samego rana skakał jak linoskoczek, zwijał się wśród pudełek, wypisywał sygnatury” (PklO, 84), a także w samej pracowni naukowej. Mieściło się w niej tzw. podręczne lektorium, czyli „wszelakie kompendia, leksykony, źródła dziejowe w okazałym komplecie

${ }^{8}$ Mieczysław Opałek, Ze wspomnień lwowskiego bibliofila (Rzeszów: Mitel, 2001), 44.

${ }^{9}$ Ibidem, 46.

${ }^{10}$ Ibidem, 31. Prezesem Towarzystwa został Jan Kasprowicz (ibidem, 32).

${ }^{11}$ Vide Andrzej Zieliński, „Noty biograficzne bibliofilów i lwowskich antykwariuszy”, in ibidem, $176,178$.

${ }^{12}$ Stanisław Wasylewski, Pod kopuła lwowskiego Ossolineum. Pamiętnik stypendysty i asystenta Zakładu Narodowego im. Ossolinskich w latach 1905-1910 (Wrocław: Zakład Narodowy im. Ossolińskich, 1958), 77-79. Wszystkie przytaczane dalej fragmenty wspomnień Wasylewskiego pochodzą z tego wydania i będą oznaczane bezpośrednio po cytacie za pomocą umieszczonego w nawiasie skrótu tytułu: PklO oraz liczby arabskiej oznaczającej numer strony. 
oraz rzecz bardzo ważna i wertowana co chwila: herbarze" (PklO, 102). Pracownią tą kierował w latach 1906-1908 Juliusz Kleiner - również stypendysta ossoliński (PklO, 59), przyszły historyk literatury.

Stypendyści postrzegali niewątpliwie Ossolineum jako miejsce gromadzenia, zabezpieczania i porządkowania dorobku polskiej nauki i literatury. Swoją aktywnością zdecydowanie jednak przekraczali ramy ustalonych dla nich obowiązków. Już pierwsze czynności wykonywane przez Wasylewskiego ujawniły jego szczególną gorliwość w penetrowaniu bibliotecznych zbiorów. Zlecane prace stały się da niego okazją do zagłębienia się w „nie przeczuwany dotąd w takim ogromie tysiącletni świat cywilizacji polskiej” (PklO, 91). Obsługiwanie czytelni naukowej sprzyjało zapoznawaniu się z najcenniejszymi zbiorami Zakładu:

Gdy urzędowanie moje rozpoczynało się o godz. 9, często latem już długo przedtem sterczałem na najwyższym szczeblu drabiny, aby pogłębiać i uszczelniać zażyłość ze światem książek. $\mathrm{Z}$ przesadą oczywistą mówiono, że ten Wasylewski stara się poznać osobiście każdy druk XIX-wieczny, choć po dwóch latach zbliżałem się istotnie do takiej biegłości. Sama praktyka w obsłudze naukowców, zmuszając do kontaktów, powiększała bibliognozję [PklO, 95-96].

Bibliotekarskie zadanie porządkowania i zabezpieczania zbiorów jawiło się jednak przede wszystkim jako sprzyjające pracy badawczej. Ambicją ossolińskiego stypendysty stawało się połączenie pracy bibliotekarskiej z pracą naukową. Świadectwem tej ostatniej były też rozprawy publikowane w „Pamiętniku Literackim”. Stąd Wasylewski tak dużo miejsca w swoich zapiskach poświęca opisom naukowej aktywności stypendystów, szczególnie przygotowywaniu przez nich wydawnictw bibliograficznych. Pisarz - w ramach tego typu działalności - opracował np. zestawienie bibliograficzne historii literatury i krytyki literackiej za rok 1904, które zapoczątkowało kolejne podobne inicjatywy (vide PklO, 115-117).

W zakres tak pojmowanej bibliotekarskiej pracy wchodziło również porządkowanie zgromadzonych w Ossolineum rękopisów. Wasylewski, stojąc na stanowisku, że ,jedyne w swoim rodzaju nabożeństwo przedstawia każda lekcja krytyki tekstu" (PklO, 39), w opisie biblioteki kładł ogromny nacisk na obecne w jej zbiorach pamiątki po Juliuszu Słowackim ${ }^{13}$, które tę krytykę tekstu umożliwiały i do niej mobilizowały. Zaznaczanie obecności spuścizny Słowackiego w murach Ossolineum było w tak określonej perspektywie wzmacnianiem myśli o naukowym wymiarze pracy bibliotekarza, zwłaszcza że przy tej okazji można było wymienić wszystkich pracowników Zakładu wybijających się na polu

${ }^{13}$ Salomea Bécu - matka poety - lwowskie Ossolineum wybrała jako najlepsze miejsce do zabezpieczenia twórczości swojego syna dla potomnych. Vide PklO, 16-22. W prywatnej bibliotece Wasylewskiego znajdowały się również manuskrypty Słowackiego, podobnie jak i innych twórców romantyzmu, a także zbiór ok. 2000 autografów polskich (Bożenna Szulc-Golska, Wielkopolskie biblioteki prywatne (Poznań: Rolnicza Drukarnia i Księgarnia Nakładowa, 1929), 10-11, http://www.wbc.poznan.pl/dlibra/doccontent?id=17157 (acc. 08.04.2017)). 
edytorstwa dzieł Słowackiego, jak np. wspomniany wyżej Kleiner oraz zastępca kuratora Ossolineum Antoni Małecki (vide PklO, 23-31). Warte odnotowania jest przy tym to, że Wasylewski nie tylko eksponował trud podejmowany przez ludzi związanych z Ossolineum w celu wydawania i upowszechniania dzieł poety romantycznego, ale też działania tego rodzaju wyraźnie zespalał z bieżącą pracą bibliotekarską w Zakładzie. O własnym odkryciu jednego z zapomnianych liryków Słowackiego pisze np. jako efekcie przeprowadzanego w bibliotece skontrum.

W lecie odbywaliśmy zazwyczaj szkontrum w dużej książnicy [...]. [...] Sprawdzam numer za numerem, roczniki za rocznikiem [...]. [...] Nagle trrrrach! Jakaś plika tomów większego formatu wypada $\mathrm{z}$ hurkotem na podłogę. [...] Mignął mi się podpis kursywą: Juliusz Słowacki. Co to może być? [...] Parę strofek wiersza zupełnie mi nie znanego [...]. [...] Po kilku godzinach bobrowania, sprawdzania wiem już niezawodnie: ten foliant „Świtu” tylko po to wypadł na podłoge z takim hurkotem, aby mnie zawiadomić, że w tym właśnie czasopiśmie specjalnym, wśród wiadomości i artykuląt przemysłowo-handlowych kryje się nieznany, wyjątkowo piękny utwór autora Kordiana! [PklO, 53-56].

Można tę relację potraktować jako żartobliwą opowieść o przygodach młodego bibliotekarza, warto jednak zwrócić uwagę na kryjące się w niej, istotne w zarysowanym kontekście stwierdzenie, że praca w Zakładzie nakładała obowiązek nie tylko faktycznego czuwania nad stanem olbrzymiego księgozbioru i sposobami jego udostępniania, lecz także odkrywania jego tajemnic, naukowego opracowania znajdujących się w nim materiałów.

3.

Myślenie o bibliotece kategoriami instytucji naukowej ma bardzo stare tradycje $^{14}$. Trudno byłoby jednak przekonywać, że postrzeganie przez Wasylewskiego biblioteki jako przestrzeni życia naukowego ma swoją genezę wyłącznie w jego wiedzy na temat długiej historii tejże instytucji. Trzeba bowiem pamiętać, że sam Ossoliński myślał o swojej fundacji w kategoriach placówki naukowej. Wówczas, gdy przewidywał usytuowanie jej w Zamościu, w zapisach fundacyjnych wydzielił określoną kwotę na druk pisma pt. „Biblioteka Historii i Literatury Krajowej Dawnej i Teraźniejszej”"15, projektując w ten sposób w ramach

${ }^{14}$ Można tu wymienić np. bibliotekę-akademię arabską założoną w Bagdadzie w 830 r. przez kalifa abbasydzkiego Al.-Mamuna. Vide Marek Dziekan, „Działalność przekładowa w «Domu Mądrości» (Bajt-al. Hikma) w Bagdadzie”, Studia Philosophiae Christianae, no. 1 (2005): 119-120, http://bazhum.muzhp.pl/media//files/Studia_Philosophiae_Christianae/Studia_Philosophiae_Christianae-r2005-t41-n1/Studia_Philosophiae_Christianae-r2005-t41-n1-s115-127/Studia_Philosophiae Christianae-r2005-t41-n1-s115-127.pdf (acc. 15.04.2017). Pisarz nazywa Ossolineum „Domem Słowackiego" (PklO, 38), podobnie jak arabska biblioteka-akademia określana była „Domem Mądrości” (Marek Dziekan, op. cit., 119).

${ }^{15}$ Jan Trzynadlowski, op. cit., 28. 
działalności biblioteki pracę naukową służącą zachowaniu narodowego dziedzictwa i pogłębianiu wiedzy na jego temat. Można więc powiedzieć, że Wasylewski dobrze odczytał swoje bibliotekarskie zadania w kontekście misji Ossolineum, zaplanowanej przez jego twórcę.

W narracji pisarza jest jednak element sprawiający, że jego doświadczenie pracy w bibliotece Ossolińskich nabiera szczególnego wydźwięku. W swoich opisach podkreśla on bowiem fakt tworzenia się w obrębie Zakładu określonej wspólnoty bibliotekarzy-badaczy, zasłużonych dla polskiej kultury i jej dziewiętnastowiecznych dziejów. Nie bez znaczenia pozostaje to, że Wasylewski swoje biblioteczne wspomnienia poświęcił przede wszystkim ludziom tworzącym historię tej instytucji. Nawet biblioteczny katalog stał się dla niego okazją do przypomnienia wszystkich zjednoczonych praca w Ossolineum. Widział w nim kartki sporządzone pod okiem Ossolińskiego przez pierwszych stypendystów, rozpoznawał ślady pozostawione w nim między innymi przez Józefa Gwalberta Pawlikowskiego, Ksawerego Godebskiego, Karola Szajnochę, Mieczysława Romanowskiego i inne postaci ważne dla narodowego życia (PklO, 99-100).

Obraz Ossolineum tworzy się w jego relacjach w pryzmacie sylwetek wszystkich zaznaczających w nim swoją obecność. Chęć pokazania Zakładu jako miejsca tworzenia się polskiej wspólnoty zawiązanej w przestrzeni nauki i kultury uzasadnia właśnie tę - tak bardzo rzucającą się w oczy - tendencję do szczegółowego opisania jak największej liczby osób prowadzących w Ossolineum swoje badania, a także do eksponowania intelektualnych więzi łączących bibliotecznych bywalców. Z takim właśnie zamiarem wspominał relację Kleinera z Antonim Małeckim. Zwracał uwagę na fakt, że kiedy ten pierwszy w $1908 \mathrm{r}$. uzyskał stopień doktora na podstawie Studiów o Stowackim ${ }^{16}$, wówczas Małecki wystosował do niego gratulacyjny list. W ten sposób ,już na odchodnym prawie błogosławił fenomenalnego młodzieńca, który iuvans in verba magistri poszerzyć miał w przyszłości jakże wydatnie wiedzę o dziełach twórcy Samuela Zborowskiego" (PklO, 61).

Refleksje Wasylewskiego na temat uniwersyteckich autorytetów i ich kontaktów ze stypendystami nabierają szczególnego znaczenia. W opisywanej przez niego bibliotece stypendyści „wnoszą w ów wzajemny układ nauczających i uczących się zupełnie szczególny moment ludzki" ${ }^{17}$. Nie można go określać kategoriami relacji ucznia do nauczyciela, bowiem „stanowi o nim młoda osobowość, na tyle już dojrzała, że można z nią podjać proces twórczego uprawiania nauki, który merytorycznie różni się od procesu samego nauczania"18. Realizowanie

${ }^{16}$ Vide Stefania Skwarczyńska, „Kleiner Juliusz Edwin”, in Polski stownik biograficzny, vol. 12, ed. Emanuel Rostworowski (Wrocław: Zakład Narodowy im. Ossolińskich et Wydawnictwo Polskiej Akademii Nauk, 1966-1967), 581.

${ }^{17}$ Karol Wojtyła, „Żywotne tradycje uniwersytetu”, Ethos, no. 85-86 (2009): 207.

${ }^{18}$ Ibidem. 
celów naukowych w poczuciu wspólnoty uczących się i nauczających jest natomiast dla Wasylewskiego punktem wyjścia do nadawania Ossolineum podobnej roli, jaką spełniał uniwersytet. Uniwersytet bowiem, jak pisał Karol Wojtyła, jest „podstawowym miejscem [...] uprawiania [nauki - D.K.] przez k o n takt wzajemny nauczających i uczących się"19. Można oczywiście powiedzieć, że połączenie działań naukowych, realizowanych w obrębie Zakładu, $\mathrm{z}$ działaniami podejmowanymi na terenie uniwersytetu lwowskiego również było wpisane w wizję Ossolineum, jaką miał jego fundator. Naturalnym dopełnieniem działań Ossolińskiego, wiodących do zrealizowania zamierzonego dzieła, było bowiem utworzenie „katedry języka i literatury polskiej na odnowionym przez Franciszka I Uniwersytecie Lwowskim (1817)" ${ }^{20}$ oraz ułożenie Instrukcji dla profesora języka $i$ literatury polskiej ${ }^{21}$. O tym, że inicjatywa ta pozwala wnioskować o intencji powiązania biblioteki $z$ uniwersytetem, świadczy bardzo dobitnie fakt, że pierwszym profesorem tej katedry został Mikołaj Michalewicz jako zastępca kuratora Zakładu Narodowego im. Ossolińskich ${ }^{22}$. Wydaje się więc, że pisarz nie bez powodu zestawia Ossolineum z uniwersytetem, snując refleksje na temat losów ludzi nauki, łączących w swojej biografii pracę w jednej i drugiej instytucji (PklO, 88-89, 141). Dokonywane przez niego porównanie obu instytucji nabiera jednak w pewnym momencie bardzo specyficznego znaczenia. Wasylewski symbolicznie utożsamia bowiem bibliotekę z uniwersytetem. Pisze np., że „wszedłszy Pod Kopułę, stykał się po raz pierwszy z życiem uniwersyteckim, akademickim [...]" (PklO, 179). W jego wspomnieniach można znaleźć fragmenty, w których Ossolineum wprost nazywa uniwersytetem, pisząc np.: ,[...] dopiero po maturze spotykam się znów z Julkiem [Kleinerem - D.K.], i to równocześnie w obu moich uniwersytetach - w Ossolineum i w starej budzie św. Mikołaja” (PklO, 59).

Autor relacjonowanych wspomnień bardzo wyraźnie ujawniał nie tylko chęć porównania Ossolineum do uniwersytetu, ale przede wszystkim nadania bibliotece rangi uczelni. Konstatował: „To był mój właściwy uniwersytet. Bo nie na ławce seminarium i nie na wykładach, dorywczo słuchanych, uczyłem się. [...] Wychowywała mnie atmosfera murów i ludzi” (PklO, 180). Jak pisał, „,donośniejsza od głosu szanownych preceptorów była wymowa starych szpargałów, które odzywały się z tłoku białych półek w wielkiej książnicy” (PklO, 180). Za właściwą podstawę uniwersyteckiej edukacji w Ossolineum uważał obcowanie ze zgromadzonymi w nim dokumentami przeszłości. Potwierdza to też cytowany wcześniej Marceli Kosman, pisząc, że to Zakład „,dostarczał [Wasylewskiemu - D.K.]

\footnotetext{
${ }^{19}$ Ibidem, 207.

${ }^{20}$ Jan Trzynadlowski, op. cit., 36.

${ }^{21}$ Ibidem.

${ }^{22}$ Ibidem.
} 
lektur i [...] stanowił podstawowy warsztat pracy, przede wszystkim w zakresie starych druków i rękopisów" ${ }^{23}$.

Wasylewski był nawet skłonny zdeprecjonować studia uniwersyteckie ze względu na charakteryzujący je brak dostępu do źródeł. Autor omawianych wspomnień w znaczący sposób opisuje jałowe dyskusje akademickie, którym brakowało podstaw źródłowych. Wspomina, jak w studentach lwowskiej uczelni osłabł „po kilku miesiącach żarliwej pracy zapał do czytania i komentowania” (PklO, 35-38) dzieł Słowackiego, bowiem uświadomili sobie oni, że ,jest wprost nonsensem bazowanie dyskusji na wybranych przez Małeckiego fragmentach bez możności posługiwania się autografem" (PklO, 35-38). Praca bibliotekarska, zdefiniowana przez Wasylewskiego jako praca naukowa realizowana w oparciu o źródła, w najlepszy sposób spełniała w jego pojęciu wymogi uniwersyteckiego kształcenia. Chociaż Wasylewski przyznaje, że jego biblioteczna edukacja była dość chaotyczna (PklO, 91), to nie przeszkadzało mu to jednak w stwierdzeniu, że „nauka” pobierana w Zakładzie była „często pożywniejsza od prelekcji, którą trzeba było wysłuchać na uniwersytecie" (PklO, 92).

Zaskakujący może wydawać się przy tym jedynie fakt, że pojęcie uniwersytetu, oddające - według Wasylewskiego - w najlepszy sposób istotę Ossolineum i przywoływane w jego głębokim rozumieniu, zostało jednocześnie użyte w bardzo specyficznym i nieco zawężającym znaczeniu. Ossolineum było bowiem dla Wasylewskiego „uniwersytetem gnębionej polskości, i akademią nauki naszej, i bastionem spisku, gromadzącym siły, środki i ludzi do przyszłej chwili wyzwolenia" (PklO, 16). Pisarz, myśląc o bibliotece Ossolińskich uniwersyteckimi kategoriami, sprofilował jednocześnie jej rolę do edukacji w zakresie nauki i literatury czasu zaborów. Dopełnia tę myśl to, że na kartach jego wspomnień pojęcie uniwersytetu spotyka się z określeniem: „Przytułek św. Ossolina” $(\mathrm{PklO}, 60)$. Nazwa ta jeszcze bardziej eksponuje znaczenie biblioteki jako instytucji opiekuńczej wobec polskiej kultury okresu niewoli politycznej. Sugeruje jej rolę jako dającej schronienie polskiej myśli kulturowej tego czasu, przydając jednocześnie nimb świętości temu, który cały swój majątek wydał na powiększanie bibliotecznych zbiorów, a po śmierci nie miał nawet własnego grobu, gdyż jego ciało spoczęło w zbiorowej mogile w Wiedniu ${ }^{24}$.

Nie dziwi w tym kontekście również wyraźne dowartościowanie przez Wasylewskiego jednego szczególnego miejsca biblioteki, którym była część znajdująca się pod tzw. „kopułą Bema”. Autor wyraźnie akcentował swoją emocjonalną więź z tą częścią zbiorów biblioteki. Podkreślał, że podczas gdy inni zapoznawali się z „«cymeliami» najrzadszymi”, czyli ,inkunabułami rarytasami znaczonymi czterema krzyżykami [...], unikatami znanymi w jednym tylko

\footnotetext{
${ }^{23}$ Marceli Kosman, op. cit., 13.

${ }^{24}$ Jan Trzynadlowski, op. cit., 39.
} 
egzemplarzu" (PklO, 94), to on sam zatracał się w spuściźnie czasu zaborów. Wspominał: „taki Staś Łempicki dukwił nieraz długo między drukami złotego wieku, gdy ja siedziałem już dawno na drabinie w baszcie Bema" (PklO, 95). Miejsce to zostało wyróżnione w narracji Wasylewskiego już choćby poprzez tytuł jego wspomnień i traktowane było jako centrum labiryntowej przestrzeni biblioteki. Ono też stanowiło swoistą pamiątkę po powstańcu generale Józefie Bemie, który, modyfikując plany włoskiego architekta Piotra Nobile, przebudował wieżę kościoła karmelitanek, utworzył w niej kopułę, a w tejże następnie umieścił okno horyzontalne, napełniające całą basztę światłem (PklO, 95, 68) ${ }^{25}$.

Ostatecznym uwiarygodnieniem myślenia Wasylewskiego o Ossolineum kategoriami uniwersytetu jest też podkreślanie przez pisarza formacyjnej roli biblioteki w jego własnej biografii twórczej. Praca bibliotekarska pisarza nie tylko bowiem ,splotła się jak najściślej z [...] latami uniwersyteckimi, akademickimi [...]”26, ale też w określony sposób zaprojektowała jego całe życie:

Tutaj nauczyłem się - pisać [...]. Tutaj wreszcie dokonałem wyboru. Spośród kilku różnych dróg otwierających się przede mną, dróg bitych z doskonałymi widokami, wybrałem ścieżkę tylko. Była wąska, wyboista, ryzykowna, ale bądź jak bądź - swoja własna! [PklO, 180-181].

Ossoliński epizod, tak jak studia uniwersyteckie, uformował intelektualnie Wasylewskiego, co potwierdzają też współcześni komentatorzy jego twórczości. W związkach pisarza z Ossolineum znajdują oni klucz interpretacyjny do jego dorobku.

Adam Wierciński przekonuje, że w Ossolineum „przyszły pisarz czytał zachłannie, szperał, smakował”27 i stamtąd właśnie „wyniósł kapitał na późniejsze, jakże płodne literacko lata" ${ }^{28}$. Perspektywę interpretacji jego prac w kontekście nabytej w ossolińskich latach umiejętności pracy ze źródłami uruchomił również Józef Kallenbach, przekonując, że popularnonaukowa aktywność Wasylewskiego jest wynikiem poszukiwań, „do których wiodła «żyłka» antykwaryczno-bibliotekarska: z pyłu foliantów lub broszur, od stu lat nie rozciętych, wyłaniały się nagle żywe postacie [...]"29. Dostrzegł on w warsztacie pisarskim Wasylewskiego „bardzo głęboki, a zawsze rzetelny podkład erudyty, eks-bibliotekarza, co wśród hałaśliwej pracy dziennikarskiej nieraz zatęsknił do owych niezwrotnych lat młodzieńczych, kiedy to Ossolineum bywało niewyczerpanym sezamem zawsze nowych wzruszeń szperacza" ${ }^{30}$.

${ }^{25}$ Cf. Stanisław Łempicki, op. cit., 13.

${ }^{26}$ Ibidem, 6.

${ }^{27}$ Adam Wierciński, Dyskretny erudyta (O pisarstwie Stanistawa Wasylewskiego) (Opole: Miejska Biblioteka Publiczna w Opolu, 2003), 5.

${ }^{28}$ Ibidem, 6.

${ }^{29}$ Józef Kallenbach, „Słowo wstępne do wydania pierwszego”, in Stanisław Wasylewski, $U$ księżnej pani (Kraków: Wydawnictwo Literackie, 1958), 6. Cit. za: Marceli Kosman, op. cit., 16.

${ }^{30}$ Ibidem. 
Można zaryzykować stwierdzenie, że Wasylewski odczytał misję Ossolineum przy pomocy Humboldtowskiej formuły uniwersytetu jako miejsca „wspierania indywidualnego rozwoju poprzez wspomaganie odkrywania i rozwijania całego potencjału umysłowego i moralnego tkwiącego w jednostce" ${ }^{31}$. Biblioteka stała się dla autora omawianych wspomnień - podobnie jak uniwersytet dla Humboldta - instytucją naukową, w której „zbiega się wszystko, co dzieje się w sferze duchowej kultury narodu” 32 , a jako taka jest ona „przeznaczona do tego, aby rozwijać naukę w najgłębszym i najszerszym tego słowa znaczeniu i przekazywać ją jako [...] celowo przygotowany materiał ku wewnętrznemu i moralnemu kształceniu" ${ }^{33}$.

Idealistycznie pojmowany cel uniwersyteckiego kształcenia stał się punktem odniesienia w myśleniu Wasylewskiego o roli i znaczeniu biblioteki, co instytucję tę wyraźnie dowartościowywało. W taki też sposób misja biblioteki - jako ocalającej dorobek polskiej kultury - po niemal stu latach od utworzenia Zakładu im. Ossolińskich zdefiniowana została jako zadanie formowania człowieka w poszanowaniu kulturowego dorobku narodu i w poczuciu ponadczasowej wspólnoty dorobek ten gwarantującej. Bibliotece - traktowanej jako strażnica polskości - nadano dodatkowo rangę instytucji wychowującej kolejne pokolenia w duchu umiłowania narodowej kultury, a tym samym projektującej jej rozwój.

\section{LIBRARY-UNIVERSITY. NATIONAL OSSOLIŃSKI INSTITUTE IN STANISŁAW WASYLEWSKI'S MEMOIRS}

\section{Sum mary}

The sketch presents an interpretation of the memories by Stanisław Wasylewski, describing his work as a volunteer, scholarship holder, and then assistant to the National Ossolinski Institute in Lviv in 1905-1910. On canvas of those memories, a question was posed about how the mission of the library established for the protection of Polish cultural heritage of the time of annexation influenced the perception and experience of its employee. The reconstruction of Wasylewski's 'ossolian biography' helped to discover the categories of the writer's thinking about the library as a university, which is created by a community of scholars and learners, in which the most important currents of national culture cross, and thus the task of forming a man respecting cultural heritage is fulfilled.

${ }^{31}$ Joanna Schiller, „Universitas Rossica”. Koncepcja rosyjskiego uniwersytetu 1863-1917 (Warszawa: Wydawnictwo Instytutu Historii Nauki PAN, 2007), 18.

${ }^{32}$ Wilhelm von Humboldt, „Organizacja instytucji naukowych”, trans. Bolesław Andrzejewski, in Bolesław Andrzejewski, Wilhelm von Humboldt (Warszawa: Wiedza Powszechna, 1989), 240. Cit. za: Joanna Schiller, op. cit., 19.

${ }^{33}$ Ibidem. 